Volume I Tahun 2021

November 2021
E-ISSN: 2808-5361

http://e-journal.fkmumj.ac.id/
Proceeding The First

Muhammadiyah Internasional-

Public Health and Medicine

Conference

\title{
Knocking The Door Strategies to Increase Covid-19 Vaccination Coverage for The Elderly in The Work Area of UPTD Puskesmas Bogor Tengah
}

\author{
Karina Amalia \\ Master of Public Health Program of Public Health Faculty, University Muhamadiyah Jakarta, \\ K.H. Ahmad Dahlan St, Cireundeu, Ciputat South Jakarta, 151419 \\ E-mail: karina_amalia@ymail.com
}

\begin{abstract}
The COVID-19 vaccination aims to reduce the transmission of COVID-19, reduce morbidity and mortality due to COVID-19, achieve herd immunity, and protect the community from COVID-19 to remain socially and economically productive. UPTD Puskesmas Bogor Tengah has entered the Covid-19 vaccine service targeting the elderly from March 30 to April 10, 2021, but the coverage is still low. Coordination with cross-sectors, $R T$, and $R W$ administrators has been carried out and the result is that there are no more elderly people in the area who are willing to be vaccinated. The purpose of this study was to know the effectiveness of the knock the door strategy in increasing the achievement of Covid 19 vaccination for the elderly at UPTD Puskesmas Bogor Tengah. The method used is the descriptive method. This study was used to interview and documentation for data collection. Data analysis using qualitative analysis. The results of the study showed an increase in achievement from previously no more elderly people who were willing to be vaccinated, after conducted a knock the door strategy the achievement increased. It can be concluded that efforts to increase the coverage of the Covid 19 vaccine for the elderly require a special communication strategy and approach because the elderly have different characteristics in receiving information. The door-knocking strategy is quite effective in increasing the Covid 19 vaccination achievement for the elderly at the UPTD Puskesmas Bogor Tengah.
\end{abstract}

Keywords: Covid-19 Vaccination, Elderly Vaccination, Elderly, Knock the Door Strategy 


\section{INTRODUCTION}

The COVID 19 pandemic gives a major challenge in improving the health status of Indonesian people and has an impact on the Indonesian health system that can be seen from the decrease of performance in several health programs. Immediate intervention is needed not only in terms of implementing health protocols but also other effective interventions are needed to break the chain of disease transmission, through vaccination efforts.

COVID-19 vaccination aims to reduce the transmission of COVID-19, reduce morbidity and mortality due to COVID-19, achieve herd immunity, and protect the community from COVID-19 to remain socially and economically productive. Herd immunity can only be formed if vaccination coverage is high and distributed throughout the region. Prevention efforts through vaccination programs if assessed from an economic point of view will be much more economical.

The implementation of the COVID-19 vaccination is carried out in 4 stages. Phase 1 is an implementation time of January-April 2021 with targets for health workers, assistant health workers, support staff, and students who are undergoing medical professional educators who work at Health Service Facilities. Phase 2 an implementation time of January-April 2021 with the following targets: a. Public service officers, namely the Indonesian National Armed Forces/State Police of the Republic of Indonesia, legal apparatus, and other public service officers which include officers at airports/ports/stations/terminals, banks, state electricity companies, and regional drinking water companies, as well as other officers involved directly provide services to the community. b. Elderly age group ( $\geq 60$ years). Phase 3 an implementation time of April 2021-March 2022 with the target of vulnerable communities from geospatial, social, and economic aspects. Phase 4 is an implementation time of April 2021-March 2022 with the target of the community and other economic actors with a cluster approach following the availability of vaccines. costs, when compared to treatment efforts.

Based on the mapping carried out by the government, Puskesmas is one of the posts designated as providing vaccination services. Currently, the UPTD Puskesmas Bogor Tengah is one of the health centers in Bogor that has entered phase 2 of the vaccine service targeting the elderly (age $>60$ years). From the results of data collection, the target number of elderly in the UPTD Puskesmas Bogor is 1052 targets, divided into two sub-districts, namely Cibogor Village as many as 672 people and Pabaton Village as many as 380 people. Phase II vaccination targeting the elderly at the UPTD Puskesmas Bogor Tengah has been carried out since March 30 - April 10, 2021. The results of the evaluation of activities obtained $45.2 \%$ of achievements with details in Cibogor Village 313 people (46.6\%) and Pabaton Village 163 people $(35.8 \%)$. Coordination has been carried out with crosssector, RT, and RW administrators and the result is that there are no more elderly people in the area who are willing to be vaccinated. 
E-ISSN: 2808-5361

http://e-journal.fkmumj.ac.id/
Proceeding The First Muhammadiyah InternasionalPublic Health and Medicine Conference

This relatively low result was caused by several things, such as the target's safety and side effects of the vaccine, health conditions that made it impossible for the elderly to come to the vaccine post, and the distance that was too far. This is in line with the results of an online survey conducted during September 2020 by WHO, Ministry of Health RI, ITAGI, and UNICEF of more than 115,000 respondents in 34 provinces in Indonesia to measure public acceptance of vaccines. Various reasons for refusing or doubting the vaccine were conveyed by the public in the study. Most of the people who refuse vaccines are because they still doubt its safety (30\%) and do not believe that vaccination will be effective $(22 \%)$.

The technical instructions for the implementation of Covid 19, it is explained the communication strategy to ensure that people want to be vaccinated and continue to implement health protocols according to government recommendations. The focus of this communication design is on community empowerment activities, including planning and conducting structured house visits.

This study was conducted to see whether a structured door-knocking strategy as an innovation of interpersonal communication and a special form of approach can increase the effectiveness of the COVID-19 vaccination achievement for the elderly in the UPTD Puskesmas Bogor Tengah.

\section{METHODS}

The method used in this research is descriptive. Data collection used structured interviews with the elderly, vaccination officers, and the Head of UPTD Puskesmas Bogor Tengah, as well as documentation from secondary data at Puskesmas. Data analysis using qualitative analysis.

\section{RESULTS AND DISCUSSIONS}

The results of the study based on graph 1 show that there is an increase in coverage results from the previous, that no more elderly people were willing to be vaccinated.

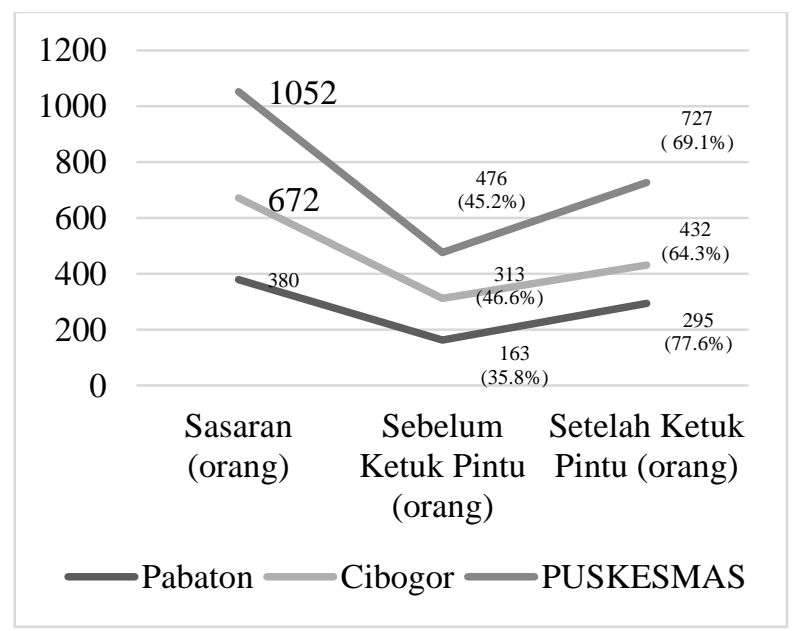

Source: Primary data from interview

After conducting a door-knocking strategy the achievement increased 132 people (41.8\%) in the Pabaton area and 119 people $(17.7 \%)$ in the area Cibogor. The total increase in the UPTD 
Puskesmas Bogor Tengah was 251 people (23.9\%) so that the total achievement after the knock the door strategy was 727 people $(69.1 \%)$.

Based on the observations, the door-knocking strategy implemented from April 15-30 2021 had a positive impact. Before conducting the door-knocking innovation, Puskesmas Bogor Tengah had carried out various health promotions regarding vaccination through social media and mass campaigns to the Puskesmas working area. In addition, information about vaccines has also been widely spread by the government through electronic media such as television, but the vaccination coverage for the elderly has only reached $45.2 \%$.

Coordination has also been carried out among cross sectors, RT, and RW to increase the coverage. The result is that there are no more elderly people who are willing to be vaccinated. The door-knocking innovation is based on a special communication theory for the elderly.

Based on the results of an interview with the Head of the UPTD Puskesmas Bogor Tengah, the door-knocking strategy is a form of innovation in social communication to increase the effectiveness of delivering messages to the target, which this case in this study is the elderly.

The elderly are mentioned as the final stage of development in the human life cycle. According to Article 1 paragraph (2), (3), (4) of Law no. 13 of 1998 about health, it is said that old age is someone who has reached the age of more than 60 years (Maryam et al, 2008 in Havifi, 2014).

Interpersonal communication is communication between people through face to face that allows each participant to capture the reactions of others directly, both verbally and non-verbally. In conducting interpersonal communication, closeness and openness are needed to establish good communication. The success of communication is the responsibility of the communicator (Mulyana, 2010).

According to Azizah and Lilik M (2011), when humans getting older, a degenerative aging process occurs which will have an impact on changes in humans, not only physical changes but also cognitive, emotional, and social, so the elderly needs special treatment in various aspects of his life.

The communication process with the elderly has to pay attention to several things, namely physical, psychological, and environmental factors to apply appropriate communication skills. In addition, it also uses full concentration in communicating with the elderly. Changes in the elderly also cause the elderly to experience difficulties in communication (Zen, 2013).

Based on the results of an interview with the Head of the UPTD Puskesmas Bogor Tengah, the door-knocking strategy is an innovation of interpersonal communication and a special approach for the elderly to increase the achievement of Covid-19 vaccination for the elderly at the UPTD Puskesmas Bogor Tengah.

In knocking on the door, the officers carry out interpersonal communication, paying attention to good language, simple sentences that is easy to understand, low tone of voice, and giving the 
elderly the opportunity to express their opinions and feelings. In addition, non-verbal communication such as eye contact and touching is also carried out. Communication is conducted at the elderly's home, the most comfortable place for them so that when the communication is delivered to the elderly there is no disturbance of comfort. Besides verbal and non-verbal communication, officers also check the vital signs of the elderly to ensure that their condition generally meets for vaccination, as well as a caring touch that can be felt by the elderly.

This is following the communication theory for the elderly according to Zen (2013) that is communicating with the elderly several techniques can be used, namely: 1) Approaching the care of the elderly physically, psychologically, socially, and spiritually and showing respect and concern; 2) Using good language such as using simple and short sentences, the appropriate speed and voice pressure, give the elderly opportunity to talk, avoid "yes" and "no" question and change the topic of conversation if the elderly are not interested more ; 3) Nonverbal communication which includes behavior, eye contact, facial expressions, posture and body, and touch; 4) Improve communication with the elderly by initiating contact. 5) The communication atmosphere must be created as comfortably as possible, for example sitting opposite, maintain privacy, adequate lighting, and reduce noise.

During the home visit and after the communication was carried out, most of the elderly were willing to express their feelings and worries about the vaccine. Officers help provide explanations and understanding so in the end the elderly can make decisions about themselves. This is following the theory according to Nugroho (2009) that the purpose of communicating with the elderly is to foster the confidence of the elderly to caregivers; give the elderly a sense of security and comfort in expressing their feelings; meet the needs of the elderly for affection; train the elderly to develop speaking, listening, and receiving stimulation; maintain the ability of the elderly to make decisions; and create or enhance social relations in society.

Besides communicating directly with the elderly, during home visits, officers also communicate with the elderly's families. This is important because the role of the family for the elderly is very big. This is following the theory according to Mubarak, et al (2011) that the family is the main support system for the elderly in maintaining their health. The role of the family includes maintaining or caring, maintaining or improving the mental status of the elderly, anticipating socioeconomic changes, and providing motivation.

After conducting a two-week knocking the door strategy, Puskesmas Bogor Tengah again carried out vaccination activities from 1 - 8 May 2021 and the vaccine coverage for the elderly increased from previously reach $69.1 \%$, with a total increase of $23,9 \%$. This shows that the knocking door strategy is quite effective in increasing the coverage of Covid 19 vaccinations for the elderly at the UPTD Puskesmas Bogor Tengah. 


\section{CONCLUSIONS AND SUGGESTIONS}

Based on the results of the study, it can be concluded:

1. To increase the coverage of the Covid 19 vaccine for the elderly, it is needed special methods and strategies because the elderly have different characteristics in receiving information

2. Knocking the door strategy is quite effective in increasing the Covid 19 vaccination achievement for the elderly at the UPTD Puskesmas Bogor Tengah

Some suggestions that can be used to continue to increase the coverage of covid 19 vaccination for the elderly include:

1. Continuing to maintain communication with the elderly by conducting regular home visits

2. Involving elderly families in educating the importance of the Covid 19 vaccine for the elderly

3. Conducting post-vaccination monitoring and handle complaints felt by the elderly.

\section{REFERENCES}

1. SK Dirjen Nomor HK.02.02/4/1/2021 Tentang Petunjuk Teknis Pelaksanaan Vaksinasi dalam Rangka Penanggulangan Pandemi Covid-19

2. Zen, Pribadi (2013). Panduan komunikasi efektif untuk bekal keperawatan profesional, Yogyakarta: D-Medika

3. Widyo Nugroho (2010) .Modul Teori Komunikasi Verbal dan Nonverbal , Jakarta: Raja Graffido Perkasa

4. Azizah, Lilik Ma'rifatul (2011). Keperawatan Lanjut Usia. Yogyakarta : Graha Ilmu

5. Mubarak. W. I. (2011). Promosi kesehatan. Jogyakarta : Graha ilmu.

6. Mulyana, D. (2010). Ilmu Komunikasi Suatu Pengantar. Bandung: PT Remaja Rosdakarya

7. Havifi, I. (2014). Komunikasi Interpersonal Perawat dengan Lansia Panti Jompo Upt Khusnul Khotimah di Kota Pekanbaru, 1(2), 1-12. Retrieved from https://jom.unri.ac.id

8. Cristanty, M., \& Azeharie, S. (2016). Studi Komunikasi Interpersonal Antara Perawat Dengan Lansia Di Panti Lansia Santa Anna Teluk Gong Jakarta. Jurnal Komunikasi, 8(2), 170-178. Retrieved from https://journal.untar.ac.id

9. Maskhuri (2017). Komunikasi Interpersonal Perawat dengan Lansia. 7-16. Retrieved from https://core.ac.uk 